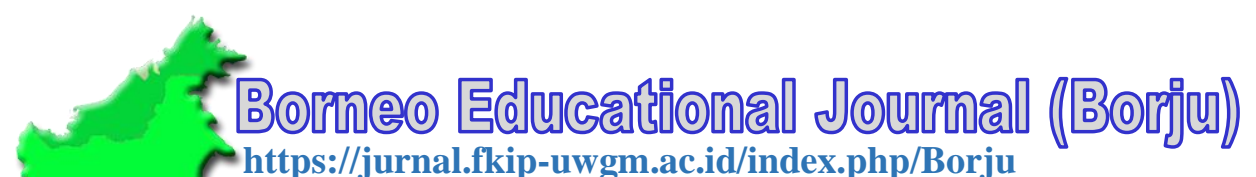

https://jurnal.fkip-uwgm.ac.id/index.php/Borju

E-ISSN: 2655-9323

August 2020, Vol.02 No.02

\title{
Improving Speaking Skills in English through Advertising Language
}

\author{
M Firas Al Farisi ${ }^{1}$, Godefridus Bali Geroda ${ }^{2}$ \\ Universitas Widya Gama Mahakam, Indonesia ${ }^{1,2}$ \\ Email Correspondence: firas.elfarisi01@gmail.com
}

\begin{abstract}
The entry of social life, human communicate with Language, there are many Languages made by agreement from the community of people, in the era of industrial technology, Advertising Language is one of the Languages that use ability to speak, The ability to handle conversations in real-time through advertising skills. The purpose of this study is to investigate features of advertising Language as a method of learning speaking English. This paper utilized Observation and Interview to gather the data. There are take Primary and Secondary data. The results of this study show the used of Advertising Language on the video assignment by the students are containing the features of advertising Language, and the result of the interview session that student helpful with the advertising Language to speech and supporting that can improve speaking English skills. Advertising Language have basic representations of perception that are interesting. Therefore, the researcher found that the function of the advertising Language features used had helped the subject speak both consciously and unconsciously, as a result of observations and in-depth interviews, the students have their own narrative that they fully supported the advertising Language itself use as a method of improving speaking English skills on the future.
\end{abstract}

Keywords: Advertising Language; Speech; Features of speech

\begin{tabular}{|c|c|c|}
\hline DOI & $:$ & https://doi.org/10.24903/bej.v2i2.626 \\
\hline Received & : & February 2020 \\
\hline Accepted & : & April 2020 \\
\hline Published & : & August 2020 \\
\hline $\begin{array}{l}\text { Copyright and } \\
\text { License }\end{array}$ & : & $\begin{array}{l}\text { Authors retain copyright and grant the journal right of first publication with the } \\
\text { work simultaneously licensed under a Creative Commons Attribution } 4.0 \\
\text { International License that allows others to share the work with an acknowledgment of } \\
\text { the work's authorship and initial publication in this journal. } \\
\text { CC C }\end{array}$ \\
\hline
\end{tabular}




\section{INTRODUCTION}

Human are social creatures that always need each other. The way they are connect to each other by communicating through Language and speech. In social life, human communicate with Language, as people know there are many Languages in this world. The ability to handle conversations in real-time through advertising skills, which use wordplay, figurative Languages, and mixed Language styles . From the statement above, it can be concluded that the advertising Language is a complex Language and it can be trained with Language style.

Advertising as a complex Language which means of conveying information to the public must be able to spread information to a large number of people in a very limited period, so that advertising is everywhere in today's society.

In education, especially learning to speak English, there are several problems that occur Problems faced by a student to be able to learn to speak English, Khalil Jahbel, said that communication problems that often occur are divided into two types, first is external and second is internal, internal problems are problems implies cognitive factors such as intelligence; Language skills; and Language learning strategies, and affective factors such as motivation, anxiety, ability to take risks; willingness to communicate; Language attitude; Meanwhile, external problems refer to social class, first Language, teacher, and curriculum. Therefore, finding solutions to solve speaking problems is very important so students can speak English better.

\section{METHODOLOGY}

Researchers use a case study as a study design, by applying a qualitative approach to this study so that the study can be explored with a deeper approach. Based on [1] there are five areas of qualitative study: case studies, ethnographic studies, phenomenological studies, grounded theory studies, and content analysis. Furthermore, the researcher chose one of the English classes at Widya Gama Mahakam University of Samarinda that is semester III FKIP English department, because it considered very appropriate and in the span of that semester there still many obstacles in his ability to speak English, therefore researchers chose and studyed this place.

[2] states that in his book, researchers are the main instrument in qualitative study, but to support this study a supporting instrument is needed. Since this study uses a case study method and a qualitative approach, this study uses observation as primary data to find results 
based on study problems. In qualitative study, data is collected and recorded in the form of an explanation, re-grouping, and matching data with study questions.

\section{FINDINGS}

According to AM, in her video assignment of 3-minute 51-second, even not all features of the advertising Language are used, it is enough to help AM make the video of her assignment more attractive and make it better than her other friends' assignments, for example, such as using the hyperbole feature at 57 seconds, AM gives a good impression to make imagination of her audience.

According to AP, on her video duration of 2 minutes 32 seconds, researchers found 11 features of the advertising Language she used. According to the results of the researcher's analysis, in the video the AP looks very attractive when talking, the interaction in front of the camera looks very pleasant, with full body gestures and voice intonation plays its delivery. Unlike the previous AM, AP uses more emotive Language features in speaking, so that she can play with the audience's feelings.

According to FB, in the video of her task which lasted 2 minutes and 23 seconds, the researcher found 13 features of the advertising Language she used. according to the results of the researcher's analysis, in the video it appears that FB is very fluent in speaking, as if she is enjoying it, although not all features of the advertising Language are used, but FB is more varied in speaking compared to other video assignments of his friends, for example, such as using grammatical features even in the second minute 1:41, so that adds a constructive impression.

According to OS, in the video of her assignment which was 3 minutes 28 seconds, the researcher found 9 features of the advertising Language she used. According to the results of the researcher's analysis, the video shows that OS is very expressive when speaking, which makes the audience follow the flow that he creates. Although not all features of the advertising Language are used, the OS is still fluent in speaking and can play the Language style quite well compared to other friend's video assignments, for example, such as the use of the Superlatives feature combined with Emotive Language which makes delivery more attractive in the minutes of $2: 17$.

According to RM, in the video of his assignment which lasted 1 minute 57 seconds, the researcher found 7 features of the advertising Language he used. According to the results of the researcher's analysis, in the video, RM was able to present his explanations in a relaxed and attractive manner. Although not all features of the advertising Language are used, RM is still 
fluent in speaking and can play the Language style quite well compared to other video assignments of his friends, for example, such as the use of the Imperative feature which is quite dominant which makes his delivery more attractive at 1:04 minute - 1:29

\section{DISCUSSION}

To answer the study questions, researchers conducted observations of students in the third semester of English Education on 5 students who had video speaking assignments uploaded to YouTube. These 5 people were selected on the basis of previous observations by comparing all videos totalling 34 videos, and 5 videos were determined that met the ability criteria mentioned by [3]. The results of the observations prove that the use of the advertising Language features is contained in their videos. Furthermore, the researcher found that the subjects using the advertising Language features were relatively the same when pronouncing some texts.

This study is also supported by interview data that shows the experiences, opinions, and feelings of the subject in speaking while in the video, in order to strengthen the answer that in accordance with the explanation of the advertising Language theory which consists of meaning, application, and its relationship with education in accordance with [4] . where getting the results of the five subjects stated that the advertising Language was quite interesting to study further, then 4 out of 5 subjects agreed that the advertising Language they used both consciously and unconsciously helped them in speaking English, but only one subject, namely OS not sure which features of the advertising Language used have helped him, he believes that what makes him able to communicate well is a given task. The success of learning English is reflected in their speaking skills, this means learning English is learning to use it in active oral communication [5]. Active oral communication is a part of the speaking process where there is a process of constructing meaning that involves the production, reception and processing of information. This is one advantage of the advertising Language which has a real-time information transfer process and several other skills according to the statement of .

Therefore, the results of data collection from the five subjects show that in their video assignment, they contain advertising Language features that make it look different and more attractive than other videos of their friends, in accordance with Suneetha's explanation that currently It takes skills that can attract attention and its own uniqueness so that it distinguishes the concept of advertising Language from other Languages, by relating it to the concept of Jeremy, that if you want to succeed in English you must master the ability to speak directly or orally. 


\section{CONCLUSION}

Based on findings, it is shown that the advertising Language features used by the subject in their video assignments, although not all of the features described are used, but they are quite varied. Furthermore, the researcher found that the function of the advertising Language features used had helped the subject speak both consciously and unconsciously, as a result of observations and in-depth interviews, their own narrative that they fully supported the advertising Language itself use as a method of improving speaking English skills on the future. Therefore, the researchers concluded that the results of this study were students of the English education study program, especially in the third semester, used the advertising Language features in their video assignments that improve their English speaking skills.

\section{REFERENCES}

[1] J. Wisdom and J. W. Creswell, Integrating quantitative and qualitative data collection and analysis while studying patient-centered medical home models. Agency for Healthcare Research and Quality, 2013.

[2] M. B. Miles, A. M. Huberman, and J. Saldana, Qualitative Data Analysis: A Methods Sourcebook, 3rd ed. London: SAGE Publication, Inc, 2014.

[3] D Lowe, “The Features of Advertising Language,” Oct. 21, 2013, 2013. .

[4] G. ed Cook, The Language of Advertising. Major Themes in English Studies. London: UK: Routledge, 2008.

[5] J. Harmer, How to Teach English. England: Longman, 2007. 